\title{
Studi Permukiman Kuna di Indonesia Melalui Pendekatan Multidisiplin
}

\section{Djoko Dwiyanto}

Keywords: archaeology, settlement, multi-disciplinary, method, approach

\section{How to Cite:}

Dwiyanto, D. Studi Permukiman Kuna di Indonesia Melalui Pendekatan Multidisiplin. Berkala Arkeologi, 28-35. https://doi.org/10.30883/jba.v14i1.627

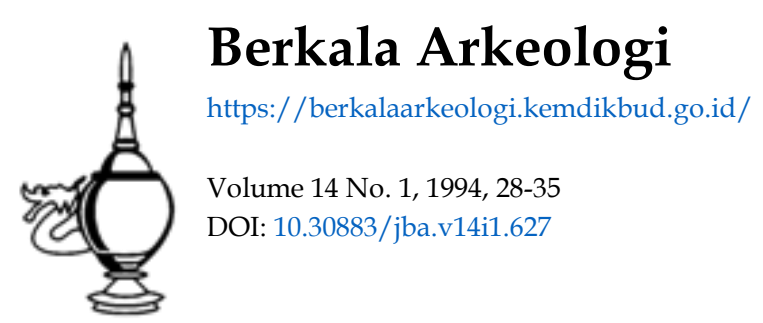

\section{(c) (1)(2) (2)}

This work is licensed under a Creative Commons Attribution-NonCommercial-ShareAlike 4.0 International License. 


\title{
STUDI PERMUKIMAN KUNA DI INDONESIA \\ MELALUI PENDEKATAN MULTIDISIPLIN
}

\author{
Djoko Dwiyanto \\ (Staf Pengajar Jur. Arkeologi FS-UGM)
}

Penelitian di bidang arkeologi akhir-akhir ini semakin berkembang pesat seirama dengan perkembangan ilmu pengetahuan dan teknologi. Perkembangan itu tidak saja tampak dari pemilihan situs, penerapan teori dan metodologi, penggunaan metode dan teknik, melainkan juga pemilihan dan penampilan subjek penelitiannya. Arkeologi yang pada awal perkembangannya hanya dikenal sebagai hobby, tidak mengherankan jika pusat perhatian mula-mula tertuju pada benda-benda yang mempunyai nilai seni. Di dalam perkembangan selanjutnya para pemerhati tidak hanya tertarik pada benda yang bernilai seni, tetapi juga yang tidak bernilai seni bahkan mencapai taraf perhatian terhadap komplek-sitas hubungan antar benda yang dapat mencerminkan berbagai aspek kehidupan manusia masa lampau.

Setelah objek penelitiannya semakin banyak, maka muncullah model klasifikasi terhadap benda-benda buatan manusia atau artefak berdasarkan fungsinya. Secara fungsional setiap artefak dapat dilihat dari segi teknomik, sosioteknik, dan ideoteknik. Klasifikasi inilah yang rupanya dapat membantu pengembangan penelitian arkeologi, sehingga sering kali muncul istilah modern-archaeology (Binford, 1962:220). Meskipun demikian sebenamya data arkeologi tidak hanya berupa artefak, tetapi juga dapat berupa ekofak (lingkungan fisik dan non fisik). Dengan gambaran data seperti itulah kemudian merangsang tumbuhnya pemilihan dan penampilan subjek penelitian yang sebelumnya tidak terbayangkan sama sekali.

Di antara aspek-aspek penelitian arkeologi yang melibatkan berbagai cabang ilmu adalah studi tentang permukiman kuna. Studi ini pada hakekatnya mengamati gejala yang terjadi dalam suatu pola pemukiman yang merupakan interaksi dari subsistem-subsistem kebudayaan yang ditunjukkan oleh tiga kelas artefak tersebut di atas. Meskipun subjek penelitian ini sudah mulai mendapat perhatian pada dasawarsa tujuhpuluhan, tetapi masih saja muncul kajian-kajian baru 
terhadap unsur-unsur yang terkandung dalam suatu situs pemukiman.

Situs pemukiman sebagai tempat manusia bertempat tinggal dan melakukan aktivitasnya sehari-hari biasanya ditandai dengan sekumpulan sisa-sisa kegiatan dari komunitas tertentu ( $\mathrm{Ph}$. Soebroto, 1983:1176). Oleh karena itu indikator-indikator situs ini dapat berupa bekas jalan dan bangunan, serta sampah. Demikian banyaknya aspek yang terkandung dalam suatu situs pemukiman, maka kajian terhadap situs pemukiman menuntut keragaman perangkat metode, teknik, dan pendekatan. Untuk mengintegrasikan penelitian tentang situs pemukiman, pada umumnya ditekankan pada "pola pemukimannya". Pola pemukiman adalah cara yang dilakukan oleh manusia di dalam mengatur dirinya di lingkungan kehidupannya sendiri. Dengan demikian pola pemukiman dapat menunjukkan tempat tinggal manusia, susunan bangunan, sifat dan watak bangunan yang pada gilirannya dapat merefleksikan alam lingkungannya, tingkat penguasaan teknologi serta pranata yang berlaku dalam suatu komunitas (Parson, 1972:128).

Berdasarkan gambaran tentang studi pemukiman kuna di atas, maka sekurang-kurangnya dapat dikajo lebih lanjut berbagai aspek seperti misalnya pola pemukiman, sistem kehidupan, demografi atau kependudukan, hubungan sosial, dan lingkungan serta tipologi situs. Kajian itu seringkali berdiri sendiri-sendiri maupun berhubungan satu dengan lainnya.

Berbagai aktivitas manusia yang diekspresikan melalui pola pemukiman pada dasarnya dapat berwujud mikro dan makro. Pola pemukiman dalam bentuk makro dapat berupa bangunan atau susunan bangunan yang disusun oleh komunitas tertentu, sedangkan pemukiman makro memberikan gambaran tentang hubungan antara komunitas di suatu situs dengan komunitas di situs lain. Dengan demikian pola pemukiman makro dapat menunjukkan pula distribusi situs-situs pemukiman dengan berbagai aspek perubahan, sehingga memberikan peluang untuk mengkaji dalam tingkat wilayah. Di dalam istilah lain bentuk pola pemukiman dapat dibedakan menjadi pola pemukiman komunitas dan pola pemukiman zonal (Sanders, 1969:116).

Studi tentang pola pemukiman juga dapat memberikan gambaran tentang sistem kehidupan manusia sesuai dengan leingkungan situs yang ditunjukkan. Berbagai jenis temuan dalam suatu situs dapat 
memberikan gambaran sesuai dengan sifat dan karakternya. sisa-sisa makanan dan alat-alat pertanian memberikan gambaran tentang sistem kehidupan bertani, berbagai jenis dan bentuk alat rumah tangga menggambarkan spesialisasi sehingga dapat menunjukkan sistem kehidupan sebagai pengrajin, demikian seterusnya sampai pada sistem kehidupan perdagangan yang dapat memberikan kemakmuran bagi komunitas yang bersangkutan.

Pusat perhatian terhadap kependudukan dalam arkeologi, khususnya di Asia Tenggara lebih menyeruak setelah Clifford Geert (1963) mengatakan bahwa gejala kependudukan di Pulau Jawa baru terwujud pada awal abad ke-19 sebagai akibat dari sistem kultuurstelsel yang diciptakan oleh pemerintah Hindia Belanda. Data arkeologi di Pulau Jawa dapat menunjukkan bukti bahwa sejak seribu tahun yang lalu dapat dianggap bahwa Pulau Jawa mempunyai kepadatan penduduk paling padat di dunia. Penjelasan terhadap konstatasi itu hendaknya dapat dijawab melalui kajian tentang pola pemukiman Jawa dari waktu ke waktu, dilengkapi dengan kajian terhadap hubungan antara kepadatan penduduk, lingkungan alam dan faktor sosial-ekonomi dalam kebudayaan Jawa (Miksic, 1986:5). Prakiraan tentang jumlah penduduk dapat dilakukan dengan berbagai cara, antara lain yang paling sederhana adalah dengan menentukan luas situs (dengan survei permukaan misalnya), kemudian ditentukan suatu angka sebagai perkiraan yang dapat mewakili kepadatan penduduk rata-rata per hektar. Angka tersebut dapat diambil atas dasar analogi dengan data etnografi dari wilayah yang sama. Cara lain dapat ditempuh dengan menyelidiki jumlah gerabah yang dipakai pada sebuah rumah serta lama waktu pemakaiannya sebelum pecah (lbid, hlm. 9). Di dalam studi tentang pemukiman kuna bahkan dapat dilakukan dengan cara menghitung jumlah bangunan, dengan prakiraan setiap bangunan dihuni oleh sekian jiwa dan seterusnya diperkalikan. Cara ini diperkuat dengan temuan artefaktual alat-alat rumah tangga.

Dari studi tentang pemukiman kuna juga dapat dikaji tentang organisasi sosial dan hubungan sosial masyarakat yang bermukim di situ. Selain ditunjukkan malalui tata letak dan susunan serta fungsi bangunan, organisasi sosial seringkali juga dapat ditunjukkan denga tempat penguburan. Kajian terhadap cara penguburan dapat menunjukkan status orang yang dimakamkan. Demikian pula hubungan sosial kekerabatan seringkali tergambar dari tempat penguburan, karena biasanya suatu komunitas memiliki tempat penguburannya sendiri, 
sehingga dapat diketahui komunitas mana yang dikuburkan dalam tempat penguburan itu. Meskipun dengan bertambahnya penduduk menyebabkan adanya perpindahan atau mobilitas keluarga komunitas ke tempat lain, tetapi mereka masih menggunakan penguburan komunitasnya yang lama sehingga sekali lagi dapat diketahui hubungan sosial kekerabatan dari komunitas yang menghuni kuburan tersebut. Gambaran tentang organisasi politik dari tempat-tempat penguburan juga dapat ditunjukkan, misalnya suatu komunitas pada waktu-waktu tertentu masih mengadakan upacara di tempat-tempat penguburan. Kebiasaan ini biasanya dilandasi adanya rasa solidaritas atau penghormatan terhadap orang-orang yang dimakamkan di tempat itu sebagai akibat dari peristiwa atau korban politik. Selain itu hubungan antara pola pemukiman dengan struktur sosial, misalnya organisasi sosial-politik atau organisasi seremonial seringkali juga dapat menggambarkan adanya hubungan-hubungan sosial dan dinamika-dinamika sosial yang ada di dalam pemukiman itu. Lebih lanjut secara singkat dpaat disebutkan bahwa untuk mengkaji suatu institusi atau pranatapranata sosial, politik dan seremoni juga dapat dilihat dari tata letak, ukuran luas, gaya dan tipe bangunan. Melalui tata letak dan ukuran bangunan, misalnya dapat diperoleh gambaran tentang susunan keluarga dan jumlah anggota keluarga. Penghitungan terhadap gejala ini selain berguna bagi kajian terhadap hubungan sosial juga berguna bagi penghitungan jumlah penduduk atau kependudukan. Dari sisi politik, misalnya digambarkan antara lain dengan terdapatnya bangunan benteng-benteng dan dilengkapi dengan menara-menara, tembok yang tebal, tempat-tempat pengintaian dan sebagainya. Setelah data ini dikombinasikan dengan sumber-sumber tertulis di Indonesia khususnya, maka mengenai peperangan sudah disebut sejak abad ke-7 namun demikian hanya salah sebuah situs pertahanan pada masa sebelum abad ke-16 ditemukan, yaitu di Bawang, Lampung yang diduga berasal dari abad ke-10 M (Miksic 1986:15). Kurangnya temuan situs pertahanan ini antara lain juga disebut disebabkan oleh adanya sifat-sifat dari masyarakat Indonesia yang memilih siasat lain, yaitu dengan mundur ke pedalaman dari pada menghadapi musuh.

Faktor lain yang perlu diperhitungkan dalam studi tentang pemukiman kuna adalah lingkungan. Sifat-sifat kondisi lingkungan sangat besar pengaruhnya terhadap pemilihan lokasi pemukiman, pemilihan, bahan bangunan serta perangkat akomodasi lainnya, sehingga susai dengan kondisi alam sekitarnya. Pengamatan terhadap 
tipe bangunan dan karakteristik bahan bangunan dapat menunjukkan kondisi iklim dan lingkungan alam sekitar pemukiman itu. Di dalam arkeologi dikenal dengan ekofak, yaitu data lingkungan yang mendukung adanya data artefaktual, baik fisik maupun nonfisik. Lebih jauh dapat diketahui bagaimana strategi adaptasi manusia yang menghuni pemukiman itu atau pola pemukiman itu menggambarkan suatu strategi adaptasi suatu komunitas tertentu. Dengan demikian faktor lingkungan mempunyai peranan yang cukup penting disebabkan karena suatu komunitas biasanya akan menempati suatu jaringan pemukiman dengan pertimbangan apakah tempat itu cukup mampu dalam memenuhi kebutuhan hidup setiap musimnya. Jika potensi ekologis tidak dapat mendukung pemenuhan kebutuhan hidupnya, maka suatu komunitas akan menempati suatu jaringan pemukiman dengan pola berpindah-pindah sesuai dengan musimnya. Dari berbagai aspek kajian dalam studi pemukiman kuna di atas, maka hasil sampingan dapat diperoleh antara lain dapat diketahuinya distribusi situs-situs pemukiman dalam suatu wilayah tertentu. Demikian pula secara tidak langsung melalui data arkeologis yang terkandung dalam situs pemukiman akan dapat diketahui tipologi situs itu dalam unit-unit yang lebih kecil. Namun demikian seperti telah disebut di muka seyogyanya penelitian arkeologi pada umumnya dan studi pola pemukiman pada khususnya, sebaiknya dilakukan terhadap suatu kawasan tertentu atau suatu wilayah tertentu agar ditemukan gambaran secara komprehensif dan terpadu.

\section{III}

Sepanjang pengetahuan penulis, penelitian terhadap pola pemukiman baru terbatas pada situs-situs secara terpenggal-penggal, belum terpadu. Suatu kajian tentang pola pemukiman kuna akan memberikan hasil yang menyeluruh jika arah penelitian ditujukan pada tingkat wilayah dengan pengamatan khusus terhadap pola pemukiman dan tata jenjangnya. Kajian semacam ini dapat dirancang dengan menyususn rencana umum dalam bentuk survei sistematik. Langkah pertama dapat diadakan survei secara sistematik di tingkat situs terhadap situs-situs besar yang sudah cukup dikenal seperti Trowulan, misalnya dari survei itu dapat diketahui atribut-atribut pokok dari suatu pemukiman. Pengamatan yang mendalam terhadap umur dari bagianbagian situs serta perbedaan fungsinya diharapkan dapat dijadikan 
model untuk mengungkap situs-situs pemukiman lain yang disebut di dalam sumber tertulis maupun belum. Langkah berikutnya adalah suatu survei dengan tingkat wilayah pengamatan. Sebagai contoh, misalnya wilayah Jawa Tengah dapat dibagi menjadi beberapa sub-wilayah yang masing-masing akan disurvei. Survei ini akan dilakukan secara berlapis, sehingga wilayah pesisir dan pedalaman mendapat perhatian yang sama. Dengan survei secara berlapis, dalam tingkat wilayah ini diharapkan dapat diketahui proses pertumbuhan kebudayaan tinggi dan kependudukan di Indonesia. Gagasan ini diajukan dengan suatu pertimbangan bahwa jika setiap peneltian arkeologi harus dilakukan dengan cara ekskavasi, maka akan memakan waktu dan biaya yang cukup besar. Dengan cara survei dapat dilibatkan berbagai lapisan dan tingkatan pemerhati arkeologi dengan biaya yang tidak terlalu besar. Program ini misalnya dapat menjadi agenda tahunan dari suatu pertemuan ilmiah mahasiswa arkeologi, sehingga hasilnya dapat dijadikan bahan kajian atau topik diskusi dalam pertemuan ilmiah yang kurun waktunya lebih lama misalnya tiga tahunan. mengenai studi tentang pola pemukiman, Ph. Subroto (1983) mengemukakan suatu gagasan bahwa studi ini dapat dilakukan dengan mengkaji temuantemuan arkeologis yang menunjukkan sisa-sisa habitasi untuk mengetahui distribusi dan karakternya. Dari pengkajian tersebut kemudian dicari hubungan antara kebudayaan dengan alam lingkungannya. Apabila ternyata data arkeologis itu tidak dapat menunjukkan fase-fase kebudayaan, maka dapat dicari perubahanperubahan yang terjadi dalam hubungan antara manusia dengan lingkungannya yang digambarkan oleh perubahan-perubahan dalam pola pemukiman. Dengan kata lain studi tentang pola pemukiman dapat mempunyai tujuan untuk menganalisis hubungan yang terjadi antara pola pemukiman dengan aspek-aspek kebudayaan yang lain. Dari hasil analisis tersebut kemudian dipakai sebagai dasar untuk mengetahui lebih jauh tentang kebudayaan-kebudayaan yang ditelitinya. Mengingat di dalam perkembangannya pola pemukiman sering mengalami perubahan yang disebabkan oleh faktor politis, ekonomis, maupun lingkungan, maka Ph. Subroto (1983) mengusulkan bentuk pola pemukiman di Indonesia sebagai berikut:

1. Studi tentang bangunan atau rumah secara individual

2. Studi tentang situsnya atau komunitasnya.

3. Studi terhadap distribusi situs pemukiman 
Bidang studi yang pertama dan kedua dapat dimasukkan ke dalam kelompok studi pola pemukiman mikro. Adapun bidang studi ketiga meliputi antara lain perubahan pola pemukiman yang terjadi sebagai akibat pengaruh faktor sosial, ekonomi, dan politik.

Dengan demikian secara keseluruhan studi tentang pemukiman kuna di Indonesia sudah semestinya dilakukan dengan pendekatan berbagai cabang ilmu (multidisiplin), agar dapat dikerjakan secara tuntas hal-hal yang berhubungan dengan disiplin ilmu itu. Hal ini sekaligus memberikan harapan, meskipun data arkeologi bersifat artefaktual tetapi diharapkan dapat memberikan gambaran yang jelas dan menyeluruh serta tidak kering terhadap suatu fenomena; khususnya tentang pemukiman kuna di Indonesia.

\section{KEPUSTAKAAN}

Ascher, Robert. 1968, Time's Arrow and the Archaeology of a Contemporary Community, In: Settlement Archaeology, edited by E.S/ Higgs. London: Cambridge University Press, pp. 111-176.

Miksic, John Norman., 1986, Pola Pemukiman dan Peradaban di Asia Tenggara, Kegiatan IImiah Arkeologi, IAAI Komisaris Yogyakarta - Jawa tengah, 16 Mei 1986.

Parsond, J.R., 1972 Archaelogical Settlement Patterns, In: Annual Review of Anthropology, Vol. I, pp. 127-150.

Peizer, Karl J., 1945, Pioneer Settlement in the Asiatic Tropics: Studies in Land Utilization and Agriculture Collonization in Southeast Asia. In: American Geografhical Society, special publication No. 29.

Rouse, Irving, 1968, Prehistory, Typology, and the Study of Society, In: Settlement Archaeology, edited by K.C. Chang. California: National Press Books, pp. 1-9. 
Subroto, Ph., 1983, Studi tentang Pola Pemukiman Arkeologi: Kemungkinan-kemungkinan Penerapannya di Indonesia, Pertemuan IImiah Arkeologi III, Proyek Penelitian Purbakala Jakarta: Departemen Pendidikan dan Kebudayaan, hlm. 11761186

Trigger, M.W.F., 1968 The Determinants of Settlement Patterns. In: Settlement Archaeology, pp. 53-78.

Willey, Gordon R., 1968, Settlement Archaeology: An Apraisal, In: Settlement Archaeology, pp. 208-226. 